\title{
Plány odkanalizování venkova a sucho
}

\section{Sewerage Plans in Rural Areas and Drought}

\author{
Karel Plotěnýa ${ }^{*}$, Michal Plotěnýb \\ ${ }^{a}$ ASIO TECH, s. r.o., Brno \\ ${ }^{b}$ ASIO NEW, s. r.o., Brno
}

\begin{abstract}
Abstrakt
Podle závazku při vstupu do EU má být zajištěno odpovídající řešení odpadních vod i u menších aglomerací. Což mimo jiné přispěje k dosažení dobrého stavu vod. Dalším cílem je sociálně únosná cena vody. Všechny tyto tři závazky pak v podstatě znamenají rovnici o třech neznámých, jejímž výsledkem by měl být plán jak jich dosáhnout. V České republice by měl představu konkretizovat tzv. Plán rozvoje vodovodů a kanalizací kraje (PRVK), který by měl vycházet z Plánů povodí a sociálních podmínek $\mathrm{v}$ prííslušné oblasti. Jako rozumný postup se jeví zpracování různých variant řešení odpadních vod a jejich vyhodnocení. Závěrem by měl být akt, kterým se občané obce rozhodnou pro akceptovatelné řešení. Bohužel se tak neděje a výsledkem jsou plány, které nerespektují východiska, nebo postaví občany před hotovou věc. Př́ispěvek se zabývá jevy ovlivňujícími rozhodování, které ve výsledku vedou k řešením nesplňujícím okrajové podmínky. Př́spěvek byl prezentován na konferenci ExFoS 2020.
\end{abstract}

Klíčová slova: plány rozvoje vodovodů a kanalizací, PRVK, obec.

\section{1. ÚVOD}

V současnosti dosáhla Česká republika toho, že jsou v podstatě odkanalizovány větší aglomerace než 2000 ekvivalentních obyvatel (EO); podle závazku při vstupu do EU má zajistit i u menších aglomerací odpovídající řešení odpadních vod. Vedle toho jsme si dali i úkol dosažení dobrého stavu vod, což představuje mít vyřešený venkov jako celek, minimální odlehčení realizací opatření pro hospodaření se srážkovou vodou (HDV) a mít pod kontrolou průmysl. Další omezení, které jsme si stanovili, je sociálně únosná cena vody. Všechny tyto tři závazky pak v podstatě znamenaji rovnici o třech neznámých, jejímž výsledkem by měl být plán, jak jich dosáhnout. U všech třech parametrů se předpokládá, že budou

\begin{abstract}
According to the commitments accepted in the EU accession negotiations, the Czech Republic should provide for adequate solutions for wastewater even in smaller settlements. Apart from this, we have set the task of achieving a good condition of waters, which means to solve the rural areas on the whole. Another restriction we adopted in this process is a socially bearable price of water. In principle, all the three commitments represent an equation with three unknowns, the output of which should be a plan how to meet them. In the Czech Republic, this plan should be given by the so-called Development Plan of Regional Water \&Sewer Systems (RWSS). As a prudent approach, it appears to process various options of wastewater treatment and their evaluations. In the end, there should be an act, in the course of which municipal citizens decide about a solution acceptable to them. This is unfortunately not the case and the resulting plans do not respect the ordered conditions in many cases or the citizens are informed about this as an irreversible decision often socially disadvantageous. This contribution deals with some phenomena influencing incorrect decisions. The paper was presented at the ExFoS 2020 conference.
\end{abstract}

Keywords: Development plan of regional water\&sewer systems, RWSS, municipality.

stanoveny individuálně v závislosti na lokalitě, což je logické. Povodí je specifické tím, jak je velké, jak je postaveno morfologicky, jak je ovlivněno zemědělskou výrobou. Obec pak velikostí a hustotou obyvatel a také tím, jaké má možnosti získání prostředků na řešení. Nejpodstatnější je, že v př́ípadě centrálního odkanalizování rostou náklady na jednoho obyvatele se zmenšující se hustotou obyvatel. A tak nejčastějším objektem rozhodování je, jestli odvodnit centrálně nebo decentrálně. Novým faktorem při rozhodování může být nástup sucha a adaptace na změnu klimatu. Problémem zejména pro občany (obec) je, pokud se nechá ovlivnit nějakým názorem bez toho, aby si jej prověrila vícekriteriálně. Často tak obec vydá statisíce na projektovou dokumentaci bez toho, aby měla záruku, že zvolila řešení splňující obecné požadavky, a to nejlepši řešení pro 
občany. Odpovídají povodí a vodoprávní úrady za své požadavky, pokud vyžadují konkrétní řešení, které se ukáže nerealizovatelné?

\section{HISTORIE A SOUČASNOST PRVK}

\subsection{Stav PRVK po stránce legislativní}

Návrh plánu rozvoje vodovodůa a kanalizací před jeho schválením kraj projedná s obcemi, vlastníky a provozovateli vodovodů a kanalizací v území, jehož se plán rozvoje vodovodů a kanalizací týká, s Ministerstvem zemědělství, př́slušným správcem povodí a s př́slušným vodoprávním úřadem.

V př́ípadech, kdy se plán rozvoje vodovodů a kanalizací dotýká ochranných pásem př́rodních léčivých zdrojů, zdrojů prírodních minerálních vod ryzích a prírodních léčebných lázní a lázeňských míst, zpracovatel návrhu plánu rozvoje vodovodů a kanalizací projedná tento návrh s Ministerstvem zdravotnictví, a dotýká-li se plán rozvoje vodovodů a kanalizací chráněných území a ochranných pásem v oblasti ochrany životního prostředí, zpracovatel návrhu plánu rozvoje vodovodů a kanalizací projedná tento návrh též s Ministerstvem životního prostředí.

\subsection{Stav PRVK po stránce věcné}

Stav PRVK je $\mathrm{v}$ jednotlivých částech republiky různý. Zejména u malých obcí obsahuje, co se týká odkanalizování, neověřené vize (nerealizovatelné finančně jak po stránce investic, tak podmínek pro dotace) anebo alibistická řešení - obec bude řešena jímkami na vyvážení (což je neúnosné pro občany a zcela mimo hranice sociální únosnosti ceny vody. Důvodem pro neutěšený stav je všeobecně podporovaný názor, že decentrální řešení jsou nefunkční. Namísto zlepšování systému decentrálních řešení a přijetí odpovědnosti za jejich povolování a kontrolu, vodoprávní úřady logicky podporují centrální řešení (jednodǔšśí kontrola) nebo jímky na vyvážení (alibismus).

Stav je tedy takový, že PRVK zpracovává a schvaluje kraj, $\mathrm{s}$ obcí ho jen projedná, ale obec pak navržené řešení financuje a ekonomické dopady na občany nese sama. Dokonce je povinna ve stočném uplatnit veškeré náklady včetně nákladů na tvorbu fondu obnovy, což mủže dotlačit cenu stočného i na několik stovek korun $\mathrm{za}^{3}$.

\section{DOBRÝ STAV VOD A JEHO DOSAŽENÍ}

\subsection{Souvislost mezi odkanalizováním obce a dosažením dobrého stavu}

Dosažení dobrého stavu u co nejvíce sledovaných profilů je cílem, který si Česká republika dala za cíl při vstupu do EU. Odkanalizování aglomerací větších než 2000 EO je také zhruba hotovo, přesto stále většina lokalit $\mathrm{v}$ České republice nedosahuje dobrého stavu, $\mathrm{k}$ jehož dosažení jsme se zavázali před vstupem do EU. Např. v povodí Labe je to až $85 \%$, v povodí Dunaje pak $75 \%$ [1]. Nejčastějš́i řešení, prri kterém jsou všechny domy, jakkoliv od sebe vzdálené, napojeny na jeden kanál svedený do čistírny, nebo soustředění odpadní vody v jímce vč. odvozu na čistírnu, je neekonomické a neudržitelné.

Navíc tím i přes značnou investici k odpovídajícímu zlepšení nedochází, někdy tato investice má i opačný účinek.
Soustředění vypouštěného zbytkového znečištění v místě čistírny v konkrétním místě zhorší stav a nastartuje trofizaci. V řadě lokalit, zejména tam, kde dochází k intenzivní zemědělské produkci, je centrální čistírna jako investice za několik desítek miliónů opatření, které stav toku z hlediska dosažení dobrého stavu ovlivní jen kosmeticky.

\section{EKONOMICKÉ PARAMETRY}

\subsection{Požadavek na ekonomičnost řešení}

Jednou z podmínek při zpracování PRVK uváděných v legislativě je ekonomičnost řešení. V prováděcí vyhlášce je hned v úvodu [2]:

„Plán rozvoje vodovodi̊ a kanalizací obsahuje koncepci řešení zásobování pitnou vodou, včetně vymezení zdrojů povrchových a podzemnich vod, uvažovaných pro účely úpravy na pitnou vodu, a koncepci odkanalizování a čištěni odpadnich vod v daném územním celku. Navržené koncepce musí být hospodárné a musí obsahovat řešení vztahů k plánu rozvoje vodovodů, kanalizací pro sousedici územi. “"

\subsection{Variantní řešení}

Ekonomičnost je ale nejčastěji tím, co je diskutabilní. Není výjimkou, že obec má zpracovaný PRVK, který je z tohoto důvodu nereálný. Z praxe - viz př́ípad ze Šumavy - obec 400 EO skládající se ze tř́ částí je řešena centrálně s délkou kanalizace kolem $9 \mathrm{~km}$ a výsledný investiční náklad je kolem 70 mil. Kč [3]. Již na první pohled je zřejmé (a měl by za to někdo být odpovědný), že obec vydala nesmyslně prostředky v řádech stotisíců korun na projekt, ze kterého vyplynula potřeba takové investice. Jen pro zajímavost, obec pracuje s ročním rozpočtem 7 mil. Kč. Již přes přes milion korun za takovou variantu bylo vydáno na popud vodoprávního úřadu, který by jim údajnějinou variantu nepovolil (cožje nejčastěji uváděný důvod nereálných návrhů PRVK). $\mathrm{V}$ př́padě zpracování variantních řešení a odhadu nákladů u jednotlivých variant by $\mathrm{k}$ takové situaci dojít nemohlo.

\subsubsection{Náklady jednotlivých variant}

Se snahou odvodnit centrálně i malé a roztroušené lokality rostou enormně exponenciálně náklady. Není žádnou zvláštností investiční náklad i 350 tis. Kč na EO. Pokud by tyto náklady měli nést samotní lidé, kterých se to týká, cena za odvádění odpadních vod by pro mnohé z nich byla sociálně neúnosná. Pokud by se na odvodnění měli podílet solidárně všichni připojení (nebo i stát), což se dnes děje u větš́ch lokalit, tak i pak by se úhrada na některých lokalitách s vysokým poměrem délky kanalizace na obyvatele dostávala za hranici sociální únosnosti. To stejné platí i pro vyvážení jímek - náklady na jejich instalaci a vyvážení jsou za oficiální hranicí sociální únosnosti, zejména pokud uživatelé dodržují všechna pravidla. $Z$ vysoké ceny za vyvážení proto vyplývá i vysoké riziko, že provozovatelé budou hledat „náhradní řešení“ a bude docházet $\mathrm{k}$ nedovolenému vypouštění.

Příklady ceny (v Kč) za likvidaci odpadních vod $\left(\mathrm{za} \mathrm{m}^{3}\right)$ při 20 letech životnosti objektu, hrubé orientační srovnání pro kalkulaci bez př́pojek pro $4 \mathrm{EO}$ a spotřebě $100 \mathrm{1} / \mathrm{EO} / \mathrm{den}$ je uvedeno v Tabulce č. 1. Stočné je bráno jako př́klad obvyklého stočného ve velkých městech, $v$ prrípadě propočtu pro malé obce by stočné bez solidárního přispění větší lokality činilo i stovky korun. 
Tab. 1 Orientační ceny za likvidaci $1 \mathrm{~m} 3$ odpadní vody.

Tab. 1 Approximatepricesfordisposalof 1 m3ofwastewater.

\begin{tabular}{lccc}
\hline & Investiční náklady & Provozní náklady & Náklad na m \\
\hline Veřejná kanalizace & & & asi 45 Kč \\
Skupinová ČOV pro 50 EO & 300 tis. Kč & 20 tis. Kč & asi 25 Kč \\
Domovní ČOV (tř. 1) & 70 tis. Kč & 10 tis. Kč & asi 90 Kč \\
Žumpa & 90 tis. Kč & 24 tis. Kč & asi 300 Kč \\
Sociálně únosná cena & & & asi 50 Kč \\
\hline
\end{tabular}

Z čísel uvedených v tabulce vyplývá, že z pohledu sociální únosnosti a spravedlnosti bychom měli řešit odvádění odpadních vod, pokud to jde, centrálně, a pokud se to nevyplatí, pak decentrálně. $Z$ decentrálních způsobů upřednostnit skupiny čistíren. U individuálních domovních čistíren se pak snažit minimalizovat provozní náklady (např. na vzorkování, odvoz kalu) a žumpy povolovat jen zcela výjimečně, což v podstatě nařizuje i legislativa - viz vyhláška č. 269/2009 Sb., kterou se mění vyhláška č. 501/2006 Sb., o obecných požadavcích na využívání území.

\subsection{Solidárnost a její uplatnění}

Solidárnost je možné chápat více směry. $V$ tomto př́ípadě jde o to, že náklady na odkanalizování finančně náročné části nesou všichni připojení na sít'. Pochopitelné je to tam, kde je hospodárné z celkového pohledu. Solidárnost je nutné podporovat tam, kde jde opravdu o nejoptimálnější řešení celku jak po stránce sociální, tak i z hlediska celkové udržitelnosti. Naopak ji nezneužívat tam, kde jednáme nehospodárně jen $\mathrm{z}$ důvodů alibismu nebo ve prospěch nějaké organizace. Proto je potřebné, než využijeme institutu solidárnosti, hledat nejoptimálnější řešení problému s ohledem na konkrétní lokalitu (což je zvláště u zásobování vodou a řešení odpadních vod podstatné pro výsledek = dopad na sociální sféru obyvatel), řešení (varianty) komunikovat a v ideálním případě nechat na účastnících a přispěvatelích, aby se po seznámení se všemi dopady vědomě rozhodli... (viz lidé jednají ve shodě). Paradoxně pak může být nejsolidárnější řešení, kdy každý jedná sám a ostatní mu přispějí (nebo jen umožní takto individuálně jednat).

Cílem solidarity nemůže být, aby všichni byli stejně solidárně chudí, protože budou jednat neefektivně. Cílem by mělo být, aby všichni byli (solidárně) bohatí, protože budou jednat co nejefektivněji a bohatství, které vytvoří (díky menším nákladům), použijí k solidárnímu zohlednění těch, které znevýhodňují místní podmínky [3].

\section{ADAPTACE NA ZMĚNU KLIMATU}

\subsection{Př́́klad z praxe}

Vyschlý rybník a masivní úhyn ryb. V období sucha, teče v některý tocích pouze voda od obyvatelstva. V oblasti jižně pod Brnem došlo $\mathrm{v}$ suchém roce $\mathrm{k}$ tomu, že odpar $\mathrm{z}$ rybníka byl větší než $\mathrm{v}$ té době skoro nulový př́tok (nulový proto, že celá oblast je odkanalizována tak, že veškeré odpadní vody od cca 15 tis. obyvatel se čerpají mimo povodí). V době zpracování dokumentace odkanalizování tato možnost nebyla vzata v úvahu (měl na ni někdo upozornit?) a navíc povodí umožnilo odběr vody z potoka na závlahu zahradnictví.
Celkově se regulace povrchových vod mimo jiné i odkanalizováním stala nereálná - zejména chování v době minimálních průtoků. Otázkou je, kdo a jakým způsobem byl za vzniklou situaci odpovědný - zahradník, projektant, kraj, obec?

\section{IDEÁLNÍ STAV}

\subsection{Variantní řešení}

Modely, kdy jediným řešením je bud' centrální čištění, nebo jímka na vyvážení (přičemž toalety jsou splachovací), jsou již dávno překonané i v Evropě, a to hned po několika liniích. Například Německo oficiálně ustoupilo od snahy odkanalizovat celou zemi centrálně už v devadesátých letech, kdy si vyhodnotilo, že by takové počínání bylo jak neekonomické, tak i neekologické a „neudržitelné“ a podpořilo realizaci decentrálního řešení po všech stránkách - ekonomicky (dotace), legislativně (jednoduché povolování a kontrola, reálné zdůvodněné požadavky), i metodicky (byly vypracovány postupy pro zpracování územních plánů a jejich posouzení z víceparametrových hledisek ve formě ATV směrnic).

\subsection{Variantní řešení a jeho schválení z hlediska několika kritérií}

O konečném řešení by měli rozhodovat občané, kterých se to dotýká, po seznámení se s více variantami. Jediným kritériem nemůže cena, i když asi bude pro občany důležitá. Dalším důležitým kritériem může být komfort nebo odpovědnost za udržitelné řešení. To vše ovlivní cenu nemovitostí, zdraví, spokojenost občanů. Stav, kdy jediným kritériem pro volbu řešení je názor vytvořený často z doslechu, bez možnosti srovnání s dalšími variantami a schválený bez důkladného informování dotčených občanů je pro tyto občany nekorektní [4].

\section{CHYBNÉ ROZHODNUTÍ}

\subsection{Kdo odpovídá za chybné rozhodnutí?}

Nejspíše asi nekonkrétní nevymahatelná legislativa, nebo že by:

- Kraj jako zpracovatel PRVK,

- Obec jako vyjadřující se,

- Povodí, Vodoprávní úřad jako vyjadřující se ve veřejném zájmu,

- Projektant?

\subsection{Kdo odpovídá za škody za chybné rozhodnutí}

- V př́ípadně zbytečně vynaložených nákladů na nereálnou investici? 


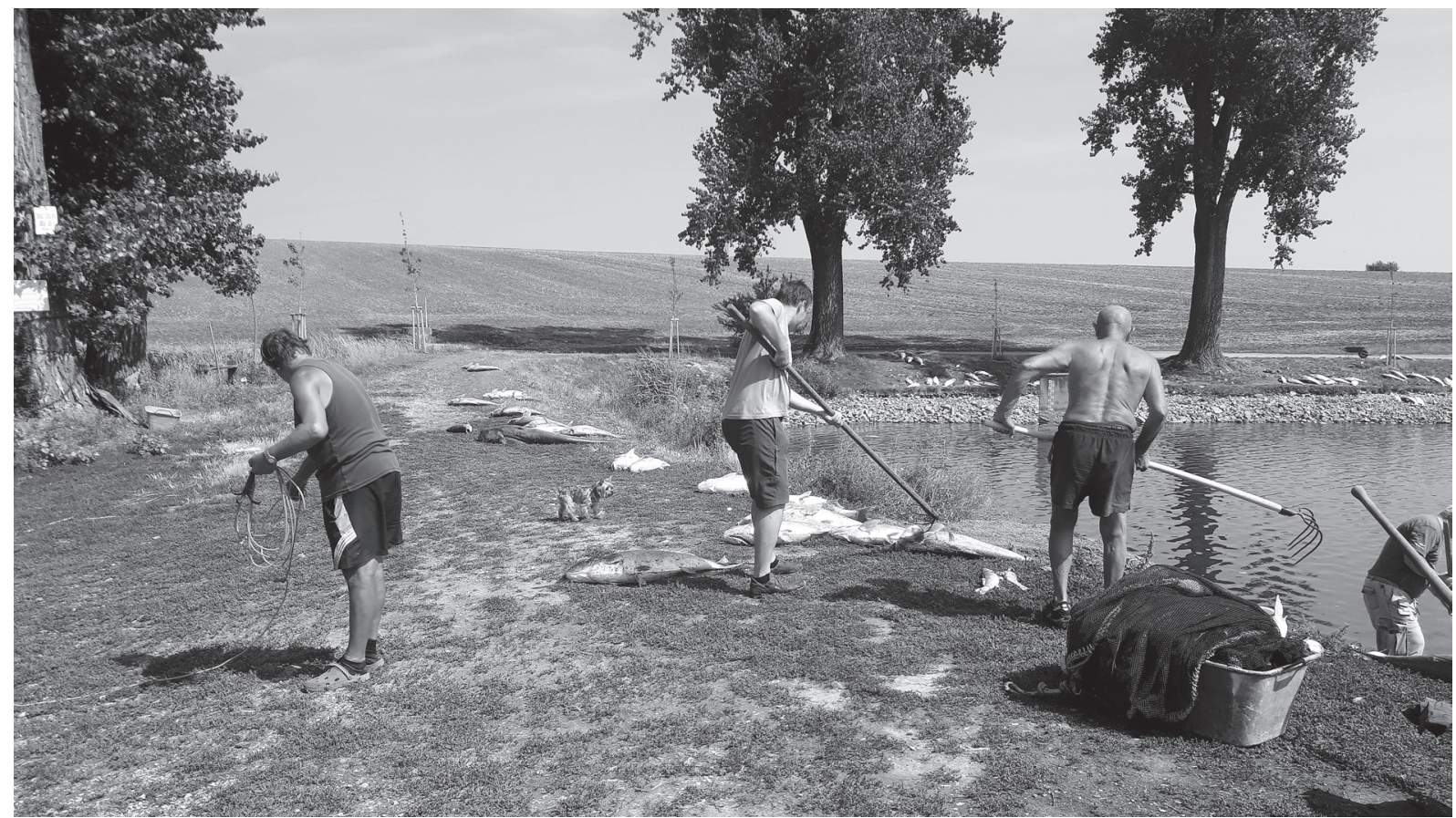

Obr. 1 Úhyn ryb na Ponètovickém rybníku v roce 2018.

Fig.1 Deathoffish on Ponétovice pond in 2018.

- Za neudržitelné anebo pro občany předražené řešení?

- Za škody vzniklé chybným řešením - např. úhyn ryb viz Ponětovický rybník 2018.

\section{ZÁVĚR}

PRVK je nástroj k optimálnímu uspořádání krajiny. Legislativa, která jej ustanovila je však „díravá“ a tedy umožňující se chovat př́mo proti základním ustanovením, a to jen na základě subjektivních pocitů. Vznikají tak značné škody jednak na životním prostředí, státu na dotacích a ve výsledku i občanům, kterým by realizovaná opatření měla sloužit ke zlepšení jejich - sociálních, ekologických a ekonomických podmínek [5].

\section{LITERATURA}

[1] VRANA, J. Nové znečištujici látky - zdroje, výskyt a charakterizace rizik. Science Party Brno 2019.

[2] Vyhláška č. 448/2017 Sb. kterou se mění vyhláška č. 428/2001 Sb., kterou se provádí zákon č. 274/2001 Sb., o vodovodech a kanalizacích pro veřejnou potřebu a o změně některých zákonů (zákon o vodovodech a kanalizacích), ve znění pozdějších předpisů.

[3] PLOTĚNÝ, K. Webové stránky firmy ASIO [online]. ASIO, spol. s r.o., [2017-06-30] Dostupné z: https://www.asio.cz/.

[4] PLOTĚNÝ, K. Udržitelnost jako hlavní kritérium při rozhodování o způsobu odkanalizování, In: Sbornik přednášek ze seminář VHOS, a.s., NOEL, Moravská Třebová, 2018, s. 1-10. ISBN 978-80-86020-86-0.

[5] PLOTĚNÝ, K., PLOTĚNÝ, M. Plány rozvoje vodovodů a kanalizací kraje (PRVK). In: Sbornik př̀spěvkủ konference ExFoS 2020. Ústav soudního inženýrství VUT v Brně, Brno, 2020, s. 301-306. ISBN 978-80-214-5829-1.

\section{Správná citace:}

PLOTĚNÝ, K., PLOTĚNÝ, M. Plány odkanalizování venkova a sucho. Soudní inženýrství, 2020, 31(2), 37-40.

DOI: http://dx.doi.org./10.13164/SI.2020.2.37. ISSN 1211-443X. 